\title{
Evaluation of the factors that make eating of hospitalized elderly difficult
}

\author{
Avaliação dos fatores que dificultam a alimentação de idosos hospitalizados
}

\author{
Evaluación de los factores que dificultan la alimentación de ancianos hospitalizados
}

Deise Feijó Lima ${ }^{1}$, Edison Luiz Devos Barlem ${ }^{1}$, Silvana Sidney Costa Santos ${ }^{1}$, Jamila Geri Tomaschewski-Barlem ${ }^{1}$, Aline Marcelino Ramos ${ }^{1}$, Kerolayne Machado de Mattos ${ }^{1}$

This study is aimed at evaluating the factors that hinder the eating of hospitalized elderly. It is a quantitative and crosssectional research, made with 92 hospitalized elderly patients in two hospitals in southern Brazil, between January and September 2012. For data collection an instrument called Eating Assessment Scale for the Elderly Hospitalized was used. A factorial and descriptive data analysis was made. Four factors related to the difficulty of eating in hospitalized elderly were identified: environmental factors, food, health team and physiological factors. The environmental factors were highlighted as the most difficult concerning eating of the elderly. It is concluded that the identified factors can contribute to the development of strategies which are aimed at assuring that the eating of the elderly occurs effectively during the period of hospitalization. Descriptors: Aged; Feeding; Malnutrition; Nursing.

Objetivou-se avaliar os fatores que dificultam a alimentação de idosos hospitalizados. Realizou-se pesquisa quantitativa, com delineamento transversal, desenvolvida com 92 idosos hospitalizados em duas instituições hospitalares do sul do Brasil, entre janeiro e setembro de 2012. Para coleta de dados, foi utilizada Escala de Avaliação Alimentar para o Idoso Hospitalizado. Realizou-se análise fatorial e descritiva dos dados. Foram identificados quatro fatores relacionados à dificuldade de alimentação dos idosos hospitalizados: fatores ambientais, alimentares, da equipe de saúde e fisiológicos. Os fatores ambientais se destacaram como os que mais dificultavam a alimentação dos idosos. Concluiu-se que os fatores identificados poderão contribuir para o desenvolvimento de estratégias que visem garantir que a alimentação dos idosos ocorra de forma efetiva durante o período de internação hospitalar.

Descritores: Idoso; Alimentação; Desnutrição; Enfermagem.

El objetivo fue evaluar los factores que dificultan la alimentación de ancianos hospitalizados. Investigación cuantitativa, con diseño transversal, desarrollada con 92 pacientes ancianos hospitalizados en dos hospitales del sur del Brasil, entre enero y septiembre de 2012. Por recolección de datos, fue utilizada la Escala de Evaluación Alimenticia para Anciano Hospitalizado. Se realizó análisis factorial y descriptivo de los datos. Fueron identificados cuatro factores relacionados a la dificultad de alimentación de ancianos hospitalizados: factores ambientales, alimenticios, del equipo de salud y fisiológicos. Los factores ambientales se destacaron como los que más dificultaban la alimentación de los ancianos. En conclusión, los factores identificados podrán contribuir al desarrollo de estrategias destinadas a garantizar que la alimentación de los ancianos ocurra efectivamente durante el período de internación hospitalaria.

Descriptores: Anciano; Alimentación; Desnutrición; Enfermería.

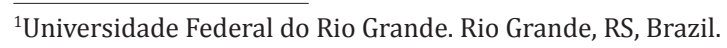

Corresponding author: Edison Luiz Devos Barlem

Rua General Osório, S/N, CEP: 96200-300. Rio Grande, RS, Brazil. E-mail: ebarlem@gmail.com 


\section{Introduction}

The epidemiological and demographic transformations in Brazil and in a great part of the world are marked by the ever growing proportion of elderly people. It is estimated that in the year 2021, the population of elderly people in the country will be equivalent to $13 \%$ of the population, bringing a series of challenges, such as the increase of the rates of chronical degenerative diseases, physical worn out resulting from the styles of living, sequelae resulting from falls, work and traffic accidents, which will possibly cause a higher number of hospitalizations, family dependence and nursing $\operatorname{care}^{(1)}$.

Even though aging is a natural process, the body of the elderly suffers nutritional alterations resulting from different factors, such as the one which involves mouth health, digestive system, chronical diseases, use of medicine, difficulty of locomotion, social and even economic aspects. Theses aspects must be evaluated once they jeopardize the health of the elderly, leading them; to malnutrition ${ }^{(2)}$.

Malnutrition is defined as a deficiency, excess or unbalance of energy, protein and other nutrients, provoking adverse effects in the form, function and physiology of the body. It is common and growing in the elderly population, where $16 \%$ of people older than 65 years and $22 \%$ of people older than 85 years are classified as undernourished. It is associated to a decline in the functional status, reduction of the body lean mass, immunological malfunction, anemia, reduction of the cognitive function, bad healing, longer period of hospitalization and increase in the rates of hospital readmission ${ }^{(3)}$.

In developed countries, $15 \%$ of the elderly people living in the community, $62 \%$ of the hospitalized ones and $85 \%$ of the ones who live in Long-term Care Institutions suffer from malnutrition ${ }^{(3)}$. In England, for example, in a gerontology ward, $71 \%$ of the hospitalized elderly presented bacterial infection in the small intestine and of those, $11 \%$ were diagnosed with malnutrition, due to the reduction and bad absorption of the nutrients ${ }^{(3)}$.

It is highlighted that the elderly people, with associate chronic diseases, become more susceptible to malnutrition. Nevertheless, the greatest part of the elderly population presents some non-transmissible chronic disease, which is responsible for frequent hospitalization and negatively influences in the context of malnutrition ${ }^{(4)}$.

Even though the population of elderly is growing, little attention has been directed to eating during old age ${ }^{(5)}$, so the precarious nutritional condition of this population shows the need to understand the singularities which contribute to malnutrition. So, the justification of this study is centered on the need that the evaluation of the factors which render the feeding of hospitalized elderly occurs effectively during the period of hospitalization, qualifying the nursing care and bringing direct benefits to the elderly patients ${ }^{(5)}$.

So, the following question is presented in the research: which factors make the eating of hospitalized elderly difficult? This research had as general objective: to evaluate the factors which make the eating of hospitalized elderly difficult and as specific objective: to build and validate the 'Scale of eating evaluation for the hospitalized elderly'.

\section{Method}

It is a quantitative cross-sectional research of the descriptive-exploratory type, made in two hospitals located in the south of Brazil, being one public and the other philanthropic. The Medical and Emergency Clinic units of each hospital were selected for the characteristics of usually presenting a higher number of hospitalized elderly. The Surgical Clinic unit was excluded once it commonly imposes routines of fast for the operatory procedures.

For this research, 92 hospitalized elderly were chosen, of which 55 were from a public hospital (H1) and 37 from a philanthropic hospital (H2). The following were criteria of inclusion: to be an elderly person, to be hospitalized for at least three days, not 
to be under any total oral, eating restriction through medical prescription, to have sufficient conditions to understand and answer the questionnaire. The elderly were selected through non-probabilistic sampling by convenience, so the selected elderly were chosen according to their presence and availability at the venue and at the moment in which the process of data collection was implemented.

The data collection, developed between January and September 2012, was made with an instrument called 'Scale of feeding evaluation of hospitalized elderly', made for this study. The instrument presents an initial part for the characterization of the subjects followed by 26 questions regarding the specific situations on the difficulties of eating of the elderly. The elaboration of the questions of the scale occurred through a revision of the literature ${ }^{(3,4-7)}$. The scale aimed at verifying the factors which provide eating of the hospitalized elderly, being operated through a Likert scale of five points: (1) It does not interfere; (2) It interferes a little; (3) It is indifferent; (4) It interferes a lot; (5) Makes it impossible. In the study the questions are presented as ' $\mathrm{q}$ ' followed by a sequence of numbers from 0 to 26 (q01 to q26).

After the elaboration of the instrument and its evaluation by a group of three experts who were nursing doctors with education in gerontology, the scale was approved with minor modifications of language. Only after the final evaluation of the experts, occurred the application of the instrument on the subjects under study, the Cronbach's alpha test was made to guarantee its validity. The Cronbach's alpha of the instrument was 0.71 , ranging from 0.72 to 0.90 in the four constructs. The total variety explained by the validated instrument was $79.22 \%$. The obtained measure of adequacy of the sample was 0.66 .

For the data collection, the visit to the selected units was adopted as a procedure, with the personal presentation of the interviewer who described the objective of the research with the acceptance of the participant and used the instrument of data collection.

For the data analysis a descriptive, statistic, explanatory and factorial analysis was made, using the Statistical Package for Social Sciences version 22.0.

The project was previously judged and approved by the Committee Ethics in Research in the Area of Health of the Universidade Federal do Rio Grande, with ordinance no. 15/2011. All the subjects signed the informed consent form.

\section{Results}

The average age of the elderly was 72.28 years; $54.3 \%$ were male and had an average of 13.7 days of hospitalization. Of the 50 elderly hospitalized men, 18 had as accompanying person the wife; of the 42 elderly women, 25 presented their children as accompanying persons. Regarding the need of help for eating, 56.5\% did not need any help. There was weight loss reported by $51.08 \%$ of the elderly and $56.5 \%$ reported that they had eaten less than usual during hospitalization.

From the exploratory factorial analysis of the 26 questions of the instrument, four constructs were formed: environmental factors, eating factors, factors of the team and physiological factors. The constructs were defined from the degree of association among the variables, found through the factorial charges (above 0.500 ) in the same block, and the degree of theoretical subjectivity in the block. 14 questions were eliminated for presenting low co-relations with the other items of their group or because of low theoretical association, and the final instrument had 12 validated questions.

Figure 1 presents the conceptual definition of the obtained constructs. Table 1 shows the result of the exploratory, factorial analysis and the formation of the constructs. 


\begin{tabular}{|l|l|}
\hline Construct & \multicolumn{1}{|c|}{ Definition } \\
\hline $\begin{array}{l}\text { Environmental } \\
\text { factors }\end{array}$ & $\begin{array}{l}\text { A series of external situations to the } \\
\text { elderly and related to the environment } \\
\text { of hospitalization which influence in the } \\
\text { decrease of the appetite }{ }^{(6)} .\end{array}$ \\
\hline Eating factors & $\begin{array}{l}\text { Related to the type of food offered, change of } \\
\text { habits, of taste, appearance, scent, variety of } \\
\text { the menu, texture and temperature besides } \\
\text { the modification of the time of the meals }\end{array}$ \\
\hline Factors of the \\
team
\end{tabular}

Figure 1 - Definition of the constructs used in the data analysis
Through a descriptive analysis, the factors which presented the highest rate in the present research were evaluated through the presented averages by each one of the 12 evaluated questions (Table 2). The construct of highest impact in the evaluation of the factors which make the hospitalized elderly eating difficult was the construct 'environmental factors', with an average of 1.36, followed by the constructs 'eating factors' and 'physiological factors' with average respectively 1.27 and 1.22. The construct of lowest average was factors of the team, with an average 1.07. Question 'q05: physiological stress' was the one with the highest average, followed by 'q06: environment odor', both in the same construct 'environmental factors'. Question 'q24: Lack of understanding/ patience by part of the nursing team' presented lower intensity and belonged to the factor with the lowest presented average.

Table 1 - Exploratory Factorial Analysis (Varimax rotation)

\begin{tabular}{|c|c|c|c|c|c|}
\hline Constructos & Block & F1 & F2 & F3 & F4 \\
\hline \multicolumn{6}{|l|}{ Environmental factors } \\
\hline q19 Excess of people/ moving around in the hospital environment & 887 & 936 & -026 & -016 & -038 \\
\hline q20 Excess of noise/ sound in the hospital environment & 861 & 926 & 030 & -011 & -047 \\
\hline q5 Physiological stress (related to environmental factors) & 776 & 873 & 091 & -021 & -067 \\
\hline q6 Environment odor & 616 & 758 & 187 & -064 & -055 \\
\hline \multicolumn{6}{|l|}{ Eating factors } \\
\hline q14 Taste of the meal & 828 & 130 & 816 & 366 & -106 \\
\hline q15 Consistence of the hospital meal (liquid, pasty or solid) & 792 & 103 & 867 & -049 & 166 \\
\hline q13 Type of food supplied & 738 & 121 & 643 & 532 & 163 \\
\hline q18 Modified eating routine (schedule) & 697 & 003 & 799 & -184 & -157 \\
\hline \multicolumn{6}{|l|}{ Factors of the team } \\
\hline q23 Food adequacy by part of the nutrition team & 727 & -077 & -005 & 847 & -063 \\
\hline q24 Lack of understanding/ patience by part of the nursing team & 782 & -055 & 046 & 881 & -036 \\
\hline \multicolumn{6}{|l|}{ Physiological factors } \\
\hline q01 Mouth health (presence of tumor, edentulism) & 886 & -089 & -014 & -044 & 936 \\
\hline q03 Use of dental prosthesis/ lack of prosthesis in the hospital & 918 & -077 & 012 & -027 & 954 \\
\hline
\end{tabular}


Table 2 - Averages presented by the constructs and individual questions

\begin{tabular}{|c|c|c|}
\hline Constructors & $\mathbf{n}$ & Average \\
\hline Environmental factors & 92 & $(1.36)$ \\
\hline $\begin{array}{l}\text { q5 Physiological stress (related to } \\
\text { environmental factors) }\end{array}$ & 92 & 1.43 \\
\hline q6 Environment odor & 92 & 1.42 \\
\hline $\begin{array}{l}\text { q19 Excess of people/ moving around in } \\
\text { the hospital environment }\end{array}$ & 92 & 1.29 \\
\hline $\begin{array}{l}\text { q20 Excess of noise/ sound in the hospital } \\
\text { environment }\end{array}$ & 92 & 1.27 \\
\hline Eating factors & 92 & $(1.27)$ \\
\hline q13 Type of food supplied & 92 & 1.28 \\
\hline q14 Taste of the meal & 92 & 1.36 \\
\hline $\begin{array}{l}\text { q15 Consistence of the hospital meal } \\
\text { (liquid, pasty or solid) }\end{array}$ & 92 & 1.25 \\
\hline q18 Modified eating routine (schedule) & 92 & 1.20 \\
\hline Factors of the team & 92 & $(1.07)$ \\
\hline $\begin{array}{l}\text { q23 Food adequacy by part of the nutrition } \\
\text { team }\end{array}$ & 92 & 1.09 \\
\hline $\begin{array}{l}\text { q24 Lack of understanding/ patience by } \\
\text { part of the nursing team }\end{array}$ & 92 & 1.05 \\
\hline Physiological factors & 92 & $(1.22)$ \\
\hline $\begin{array}{l}\text { q01 Mouth health (presence of tumor, } \\
\text { edentulism) }\end{array}$ & 92 & 1.24 \\
\hline $\begin{array}{l}\text { q03 Use of dental prosthesis/lack of } \\
\text { prosthesis in the hospital }\end{array}$ & 92 & 1.21 \\
\hline
\end{tabular}

\section{Discussion}

Among the factors which make feeding of hospitalized elderly difficult, the environmental factors showed to be the most relevant. The importance of the environment is highlighted and has been emphasized as a central access in nursing ${ }^{(7)}$. It can also be perceived that the hospital environment directly influences in the decrease of the appetite. A study made in Brazilian hospitals showed that hospitalized patients report not enjoying eating in the hospital where they find unknown people and unpleasant odors ${ }^{(6,8)}$.

As to the noise, or excess of sound in the hospital environment, they have enough potential to interfere in the physical and emotional welfare besides affecting hearing, consecutively decreasing appetite.
Equipment such as monitors, aspirators, mechanical fans, cellphones, notebooks, circulation of people, besides steps, voices/conversation of the health professionals and visitors can be considered the main hospital noises ${ }^{(9)}$. A study made in a hospital in Brazil showed that $34 \%$ of hospitalized elderly reported that the moving around of outside people or roommates, sounds of music or car noises interfere intensely in the quality of life during hospitalization ${ }^{(10)}$.

Regarding the eating factors, presented as the second of highest intensity in this research, the taste of the food is highlighted as one of the aspects for the ingestion to be adequate and the moment of the meal satisfactory. The presentation of the meal and the variety negatively contribute for the noningestion of the food ${ }^{(11)}$, besides other aspects already shown in the literature, such as texture, lack of taste and the consistence of the food ${ }^{(6)}$. Besides that, the hospitalization itself represents a rupture in the daily life of the elderly regarding the eating habits and routine, once a new eating habit is imposed, and this can generate dissatisfaction and consequent denial ${ }^{(12)}$.

The factors related to the team, formed by only two questions concerning, one with the nursing professionals and the other with the nutrition team, and they highlight the little recognition of the elderly population on the importance of these teams in their eating and nutrition. It does not seem to exist an integration between the nutritional care and the routines of diagnosis and therapy made by the health teams, which might also indicate the lack of understanding and commitment of the professionals, especially the nursing ones ${ }^{(13)}$.

The functions of the nutritionist and the nurse are distinct; the former is responsible for the whole care with the eating of the patient, its preparation and distribution. The latter is responsible for the administration and supervision of his acceptance. The nurse is responsible for feeding the patient in the same proportion that she is responsible for the medicine therapy ${ }^{(14)}$. So, observing and questioning the patient as to their eating habits, acceptance and tolerance of 
the diet, besides checking the anthropometric data and indicators of malnutrition are part of the routine of the nursing care.

Due to the social representation of the role of nursing, it seems to be common for the elderly not to attribute the care of eating to this profession. Normally, at a hospital unit, the eating care is understood by the patient as an exclusive attribution of the nutrition team, which was a limitation of the study, once it was not possible to identify whether the elderly attribute the care with eating only to the nutrition team or the nursing professionals were also considered in this aspect.

The physiological factors, formed by the mouth health questions (presence of tumor, edentelism) and use of dental prosthesis/lack of prosthesis in the hospital, reinforces the main mouth alterations present in the elderly which are caries, periodontal diseases, abrasions, lesions, mouth cancer and the loss of teeth or edentelism ${ }^{(15)}$.

It is highlighted that the partial or total absence of teeth inadequate prosthesis and the presence of tumors jeopardize the quality of nutrition. The dental loss is directly related to the nutritional condition of the elderly, once no longer being able to cut and chew the food adequately, they end up opting for food with easy ingestion, many times, less nutritious ${ }^{(15)}$.

\section{Final Considerations}

The results of this study allow to conclude that the hospital environment, especially represented by the ward in which the elderly is hospitalized, is many times, potentially considered a generator of inappetence. Controlling the flow of people who go in and out of the rooms, inspecting in order to check possible unpleasant odors, excess of sound and noise, providing a better ambiance for eating, become an important nursing care. The same way, it is concluded that the identified factors can contribute for the development of strategies which aimed at ensuring that the eating of the elderly occurs effectively during the period of hospitalization.

This study presented, as limitation, its making in two hospitals, in only one region of Brazil. Still, the possible non-comprehension of the role of nursing professionals in the context of eating of hospitalized elderly is highlighted, made evident by the answers through the use of the instrument. It is fundamental to rescue the role of nursing care concerning eating especially for the elderly population.

\section{Collaborations}

Lima DF, Barlem ELD, Tomaschewski-Barlem JG and Ramos AM contributed to the conception, field data collection, analysis, interpretation of data, writing of the article and final approval of the version to the published. Santos SSC contributed to the conception, writing of the article and final approval of the version to be published. Mattos KM contributed to the field data collection, analysis, interpretation of data and writing of the article.

\section{References}

1. Viana LAC. Challenges and prospects for nursing in the next decade. Acta Paul Enferm. 2011; 24(5):34-5.

2. Ministério da Saúde (BR). Secretaria de Atenção à Saúde, Departamento de Atenção Básica. Envelhecimento e saúde da pessoa idosa. Brasília: Ministério da Saúde; 2006.

3. Ahmed T, Haboubi N. Assessment and management of nutrition in older people and its importance to health. Clin Interv Aging. 2010; 5(1):207-16.

4. Reis SK, Santana SH, Soares BF, Medeiros SR, Serrano SMH, Moreira AS. Prevalência de desnutrição em pacientes internados em um hospital geral. Rev Dig Nutr. 2009; 3(5):477-88.

5. Mello ALSF, Zimermann K, Gonçalves LHT. Avaliação da saúde bucal de idosos por enfermeiros: validade e confiabilidade do instrumento ASBTO. Rev Gaúcha Enferm. 2012; 33(2):36-44. 
6. Demário RL, Sousa AR, Salles RK. Comida de hospital: percepções de pacientes em um hospital público com proposta de atendimento humanizado. Ciênc Saúde Coletiva. 2010; 15(1):1275-82.

7. Malta MB, Papini SJ, Corrente JE. Avaliação da alimentação de idosos de município paulista: aplicação do Índice de Alimentação Saudável. Ciênc Saúde Coletiva. 2013; 18(2):37784.

8. Wosny AM, Erdmann AL, Belli Filho P, Leite JL. The aesthetics of smells: the sense of smell and nursing. Rev Latino-am Enfermagem. 2008; 16(2):320-3.

9. Gamine JF, Silva LA, Robazzi MLCC, Sauzo SV, Faleiro AS. O ruído como um dos riscos ocupacionais: uma revisão de literatura. Enferm Global. 2010; 9(2):1-15.

10. Costa SV, Ceolim MF. Factors that affect inpatients' quality of sleep. Rev Esc Enferm USP. 2013; $47(1): 46-52$.

11. Coloço RB, Holanda LB, Mclellan KCP. Determinantes do grau de satisfação de pacientes internados referente a refeições oferecidas em um hospital universitário. Rev Ciênc Méd. 2009; 18(3):121-30.

12. Silva AKQ, Gusmão SC, Castro KR, Moreira RAN, Morais AHA. Perfil nutricional de idosos assistidos em instituição de longa permanência na cidade de Natal, RN. Rev Bras Geriatr Gerontol. 2012; 4(1):27-35.

13. Silva BT, Santos SSC, Silva MRS, Sousa LD. Percepção das Pessoas Idosas Sobre a Institucionalização: reflexão acerca do cuidado de enfermagem. Rev Rene. 2009; 10(4):118-25.

14. Garcia RWD, Padilha M, Sanches M. Alimentação hospitalar: proposições para a qualificação do serviço de alimentação e nutrição avaliadas pela comunidade científica. Ciênc Saúde Coletiva. 2012; $17(2): 473-80$.

15. Souza EHA, Barbosa MBCB, Oliveira PAP, Espíndola J, Gonçalves KJ. Impacto da saúde bucal no cotidiano de idosos institucionalizados e não institucionalizados da cidade do Recife (PE, Brasil). Ciênc Saúde Coletiva. 2010; 15(6):295564. 